\title{
MOv-gamma Chimeric Receptor Gene
}

National Cancer Institute

\section{Source}

National Cancer Institute. MOv-gamma Chimeric Receptor Gene. NCI Thesaurus. Code C2638.

A recombinant eng ineered chimeric gene derived from the murine gene encoding the variable region of monoclonal antibody MOv18 against folate-binding protein, which is often overexpressed in human ovarian cancer cells, and the gene encoding the Fc receptor for the gamma subunit of human IgG and IgE. Peripheral blood lymphocytes expressing the MOv-gamma gene may be used in the immunotherapeutic treatment of ovarian cancer. ( $\mathrm{NCl04)}$ 